\title{
Ecology and biotechnological potential of bacterial community from three marine sponges of the coast of Rio de Janeiro, Brazil
}

\author{
FÁBIO V. DE ARAÚJO ${ }^{1}$, MARCELLE C.M. NETTO ${ }^{1}$, GUSTAVO P. AZEVEDO ${ }^{1}$, MARCELLY M.A. \\ JAYME $^{2}$, MONICA C. NUNES-CARVALHO ${ }^{3}$, MARIANA M. SILVA ${ }^{1}$ and FLÁVIA L. DO CARMO ${ }^{4}$ \\ ${ }^{1}$ Departamento de Ciências, Faculdade de Formação de Professores, Universidade do Estado do Rio \\ de Janeiro, Rua Dr. Francisco Portela, 1470, Patronato, 24435-005 São Gonçalo, RJ, Brazil \\ ${ }^{2}$ Departamento de Microbiologia, Imunologia e Parasitologia, Faculdade de Ciências Médicas, Universidade do Estado \\ do Rio de Janeiro, Rua São Francisco Xavier, 524, $3^{\circ}$ andar, Maracanã, 20550-900 Rio de Janeiro, RJ, Brazil \\ ${ }^{3}$ Departamento de Bioquímica, Instituto de Química, Universidade Federal do Rio de Janeiro, Cidade \\ Universitária, Av. Athos da Silveira Ramos, 149, 21044-020 Rio de Janeiro, RJ, Brazil \\ ${ }^{4}$ Departamento de Microbiologia Geral, Instituto de Microbiologia Professor Paulo de Góes, Universidade Federal \\ do Rio de Janeiro, Av. Carlos Chagas Filho, 373, Cidade Universitária, 21941-590 Rio de Janeiro, RJ, Brazil
}

Manuscript received on June 22, 2017; accepted for publication on September 11, 2017

\begin{abstract}
Marine sponges has been a large reservoir of microbial diversity, with the presence of many species specific populations as well as producing biologically active compounds, which has attracted great biotechnological interest. In order to verify the influence of the environment in the composition of the bacterial community present in marine sponges and biotechnological potential of bacteria isolated from these organisms, three species of sponges and the waters surrounding them were collected in different beaches of Rio de Janeiro, Brazil. The profile of the bacterial community present in sponges and water was obtained by PCR-DGGE technique and the biotechnological potential of the strains isolated by producing amylase, cellulase, protease and biosurfactants. The results showed that despite the influence of the environment in the composition of the microbial community, studied marine sponges shown to have specific bacterial populations, with some, showing potential in the production of substances of biotechnological applications.
\end{abstract}

Key words: bacterial diversity, biosurfactants, enzymes, marine sponges, PCR-DGGE.

\section{INTRODUCTION}

Microorganisms can be found in different habitats in marine environments, since inanimate surfaces through the formation of biofilms until living in symbiosis with macroorganisms such as, for instance, sponges (poriferous) (Egan et al. 2008). In this association, sponges provide shelter and

Correspondence to: Marcelly Miranda Aybal Jayme

E-mail: marcellyjayme@yahoo.com.br nutrients and gain the benefit of biologically active metabolites produced by symbiotic microorganisms. Some authors suggest the term "sponge-specific" to define the association between the sponge and its microbial community as it has been shown that this community in the sponge is different from that present in seawater (Schimitt et al. 2012).

These microbial community associated to marine sponges have drawn an immense attention as 
a source for new secondary metabolites with important biotechnological properties, because of their wider biochemical accessibility, stability and higher activity than terrestrial counterparts (Kiran et al. 2014, Skariyachan et al. 2014).

Among these properties we can highlight the production of enzymes that are used to catalyze reactions in various industries with low environmental impact and cost of production (Beloqui et al. 2008, Ortega-Morales et al. 2008, Esteves et al. 2013) and biosurfactants, surface active compounds having both hydrophilic and hydrophobic domain that allows them to exist preferentially at the interface between polar and non-polar media, thereby reducing surface and interface tension, widely used in industrial and environmental applications (Banat et al. 2010, Sachdev and Cameotra 2013).

To better understand the ecology of sponge-bacteria association and evaluate the biotechnological potential of the microorganisms associated, our study aimed to compare the differences in bacterial communities present in sponges and in the marine water surrounding them and the capacity of strains isolated from sponges to produce different enzymes and biosurfactant.

\section{MATERIALS AND METHODS}

\section{SAMPLING AREA}

Sponges were collected in Itaipu beach (S-22.97, W-43.05), Niterói - RJ, Vermelha beach (S-22.95, W-43.16), Rio de Janeiro - RJ and Tartaruga beach (S-22.75, W-41.90), Armação dos Búzios - RJ.

\section{COLLECT}

Aplysina fulva and Amphimedon viridis in Tartaruga beach and Hymeniacidon heliophila in Itaipu, Tartaruga and Vermelha beaches were collected through freediving, using a spatula to remove them from the substrate. After collected, sponges were packed in sterile bags with local sea water volume and preserved on ice until processing in the laboratory. Water from the collection sites were also collected with sterile plastic bags and stored under refrigeration too.

\section{SAMPLE PROCESSING}

In laboratory, sponges were washed with sterile distilled water to remove sediment particles, some small invertebrates associated or other impurities present in their bodies. Aseptically, with the aid of tweezers and a scalpel, portions of $0.5 \mathrm{~g}$ of each sponges were removed.

To one of this portions $4.5 \mathrm{~mL}$ of sterile saline $(0.85 \% \mathrm{NaCl})$ was added to obtain 1:10 dilution. This final solution was macerated in reinforced glass tube. The final homogenate was poured into a sterile beaker and aliquots with decimal dilutions (1:10, 1:100 and 1:1000) were inoculated by spreading plate method in marine agar and incubated at $25^{\circ} \mathrm{C}$ for 1 week (Apha 2000).

After incubation period, all colonies that presented differences in its color, edge, surface, elevation, shape, brightness and size were selected and re-isolated on Marine Agar to obtain pure culture. These strains were subjected to enzymatic and biosurfactant production tests.

\section{MOLECULAR ANALYSIS}

Another three $0.5 \mathrm{~g}$ sponges portions were subjected to DNA extraction using the FastDNA SPIN Kit for Soil from BIO101 (California, USA), but instead of soil was added the $0.5 \mathrm{~g}$ of sponge. After extraction $10 x$ TE was added to give a concentration of $1 x$ TE, and the material was stored at $-20^{\circ} \mathrm{C}$. The quality of extracted DNA was evaluated in $0.8 \%$ agarose gel, applying $10 \mu \mathrm{l}$ of the sample with $5 \mu$ of dye for electrophoresis of DNA. Gels were subjected to electrical current $80 \mathrm{~V}$ in $1 \mathrm{x}$ TBE buffer for 2 hours and stained with ethidium bromide, visualized by UV transillumination and photographed with a digital camera. 
The DNA amplification was made by PCR with primers for the gene rDNA16S bacteria. The selected primers were U968f-GC1 ("clip" + 5 'AAC GCG AAG AAC CTT AC 3') and L1401r (5'GCG GTA TGT CAG CAA CC 3 ') (Nubel et al. 1997).

The $50 \mu \mathrm{L}$ reactions were performed by mixing the enzyme Taq polymerase buffer $1 \mathrm{x}, 2.5 \mu \mathrm{M} \mathrm{MgCl}_{2}$ (Invitrogen), $200 \mu \mathrm{mol}$ of each dNTP, $20 \mu \mathrm{mol}$ of each primer (Promicro), 1\% formamide, $5 \mathrm{mg}$ BSA (Sigma), 2.5U Taq polymerase (Invitrogem) and sterile Milli-Q water. In each reaction were applied $1 \mu \mathrm{l}$ DNA.

The PCR program started with the cycle of DNA strands denaturation for $3 \mathrm{~min}$ at $94^{\circ} \mathrm{C}$, followed by 35 cycles of $1 \mathrm{~min}$ at $94^{\circ} \mathrm{C}, 1 \mathrm{~min}$ at $55^{\circ} \mathrm{C}$ and $1 \mathrm{~min}$ at $72^{\circ} \mathrm{C}$, and extension at $72^{\circ} \mathrm{C}$ for $10 \mathrm{~min}$.

All PCR products were subjected to electrophoresis on $1.2 \%$ agarose gel, applying $10 \mu 1$ of the sample with $5 \mu 1$ of dye for DNA electrophoresis. Gels were then subjected to electrical current $80 \mathrm{~V}$ in $1 \mathrm{x}$ TBE buffer for 2 hours and stained with ethidium bromide, visualized by UV transillumination and photographed with a digital camera.

DGGE were performed with equipment "Dcode TM Universal Mutation Detection System" (Bio-Rad Richmond, USA). PCR products were obtained using the 16S rDNA primers, where a GC clamp described by Muyzer et al. (1993) (5'CGCCCGCCGCGCGCGGCGGGCGGGGCG GGGGCACGGGGGG3') was added to U968 primers.

$20 \mu 1$ of the products plus $20 \mu \mathrm{l}$ of the dye for DNAwere then applied directly on a polyacrylamide gel in $0.5 \mathrm{x}$ TAE buffer containing a linear gradient of denaturant from 45 to $70 \%$. Electrophoresis was performed with $75 \mathrm{~V} / 60^{\circ} \mathrm{C} / 16 \mathrm{~h}$. After the run the gel was removed from the plate and stained for 40 minutes with Syber Green I (Molecular Probes) and observed in UV, using a STORM system (Amersham) image capture.

Images of gels were used for the construction of a simple binary array where more defined bands were selected and analyzed for their presence or absence in each sample. The matrices constructed from the 16S gels were analyzed with Statistica 5.1 software (Starsoft Inc., USA), which was used for construction of dendrograms UPGA by using the coefficient 1-r Person.

\section{ENZYMATIC TESTS}

To detect amylolytic and proteolytic activity of casein were used the methods described by Williams et al. (1983) and for the detection of celullolytic activity was used the method described by Bairagi et al. (2002).

The enzymatic activity was determined by the ratio between the diameter of substrate degradation halo $(\mathrm{H})$ and the diameter of the colony tested $(\mathrm{C})$. This relationship is called enzymatic Index $(\mathrm{I})^{2}$. (I $)^{2}$ $=\mathrm{H} / \mathrm{C}$.

The strains with enzymatic index over twenty milimeters $(2 \mathrm{~cm})$ were considered strains with a high potential to degrade the substrate offered for testing (Lealem and Gashe 1994).

\section{BIOSURFACTANT TEST}

Strains were inoculated into $50 \mathrm{~mL}$ flasks containing $20 \mathrm{~mL}$ of mineral medium supplemented with $2 \%$ sucrose. The flasks were incubated under shaking $(150 \mathrm{rpm})$ at $30^{\circ} \mathrm{C}$ for $24 \mathrm{~h}$ and $48 \mathrm{~h}$. To evaluate the emulsification index, $5 \mathrm{~mL}$ of supernatant and $10 \%$ of diesel oil were placed into sterile tubes, and stirred in vortex for 20s and after 20s manually (Carmo et al. 2014). After $24 \mathrm{~h}$ and $48 \mathrm{~h}$ of this process, to enable the elimination of unstable emulsions, the reading of the emulsion index (EI) were carried out. EI was determined by the ratio between the height of the emulsified layer and the height of the total solution (Ramos et al. 2010). 


\section{MOLECULAR IDENTIFICATION (SEQUENCING)}

The strains that present the best results in the tests realized were identified by sequencing and had their genomic DNA extracted by thermal shock and purified with the Qiaquick PCR Purification Kit (Qiagen ${ }^{\circledR}$ ). After purification, the DNA underwent polymerase chain reaction for amplification of bacterial 16S rRNA using primers $27 \mathrm{FB}$ and 1492RAB. The polymerase chain reaction was performed containing Taq polymerase 5U, dNTP (25mM), 10X buffer, $\mathrm{MgCl}_{2}(50 \mathrm{mM}), 1 \mu \mathrm{L}$ of each primer to $100 \mathrm{pmol}, 1 \mu \mathrm{L}$ of DNA and sterile MilliQ water to complete $50 \mu \mathrm{L}$. The mix was then forwarded to the thermal cycler programmed with 5 at $94^{\circ} \mathrm{C}$, followed by 35 cycles of denaturing temperature at $94^{\circ} \mathrm{C}$ for $11^{\prime} 30^{\prime \prime}$, annealing temperature at $52^{\circ} \mathrm{C}$ for $1{ }^{\prime} 30^{\prime \prime}, 72^{\circ} \mathrm{C}$ extension temperature for $2^{\circ}$ and a final soak at $72^{\circ} \mathrm{C}$ for 15 . The samples were cooled to $4^{\circ} \mathrm{C}$ at the end. The amplicons were sent to the Genome Laboratory of the Department of Biochemistry at UERJ for performing the sequencing.

The sequencing was performed containing Big Dye Terminator v 3.1 sequencing buffer, $5 \mathrm{x}$ sequencing buffer, Primers 27 and 532FB and 907 and 1492RAB (3.2 pmoles/ $\mu$ l), 150ng of DNA, sterile MilliQ water to complete $10 \mu \mathrm{L}$. The mix was then forwarded to the sequencer 3500 Genetic Analyser (Applied Biosystems $^{\mathrm{TM}}$, Thermoscientific) programmed with 28 cycles of denaturing temperature at $95^{\circ} \mathrm{C}$ for 1 , annealing temperature at $95^{\circ} \mathrm{C}$ for $15^{\prime \prime}, 50^{\circ} \mathrm{C}$ extension temperature for $15^{\prime \prime}$ and a final soak at $60^{\circ} \mathrm{C}$ for 2 .

\section{RESULTS AND DISCUSSION}

\section{MOLECULAR AND ECOLOGY ANALYSIS}

To verify the differences in bacterial communities present in the same sponges species from different regions and in the marine water surrounding them we compared by DGGE the microbial communities of $H$. heliophila collected in Itaipu, Niterói, RJ and Tartaruga, Búzios, RJ.

Despite the dissimilarities in relation to water, the formation of different groups between sponges of the same species sampled from different locations, suggests an environmental influence on the composition of the bacterial communities found in these organisms (Figure 1).

It could be observed that the bacteria present in the Itaipu sponges were grouped more strongly than the group formed by the bacterial communities found in H. heliophila of Búzios. Despite this small difference between these groups; these are even more similar to each other than in relation to the bacterial communities present in waters where they occur; showing that these organisms have specific populations, which reinforces the idea that the sponges create favorable habitats for the establishment and evolution of bacterial populations, thus contributing to increasing the diversity of microorganisms, going according to several studies showing groups of bacteria specific in porifera (Schimitt et al. 2012, Kamke et al. 2010, Webster and Taylor 2012). In Schmitt et al.

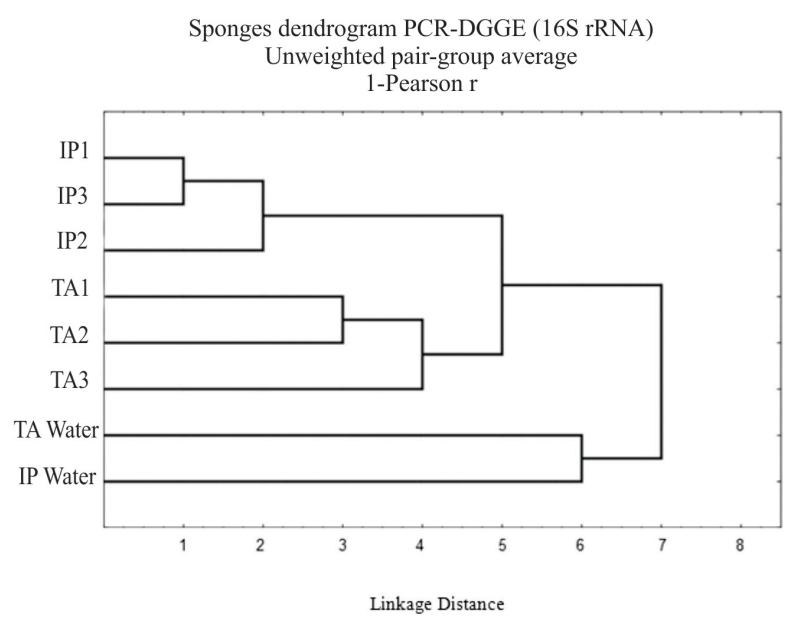

Figure 1 - Dendrogram generated using Statistica software (using Pearson and UPGA similarity coefficient) to analyze the DGGE bands profiles of samples of water and sponge $H$. heliophila of Itaipu (IP) and Tartaruga (TA) beaches. 
(2012), 32 species of sponges in several oceans and seas (Indian and Pacific oceans, Red Sea, Mediterranean, Caribbean, New Zealand and the Great Barrier Reef), were analyzed for their $16 \mathrm{~S}$ rRNA and performed the comparison of bacterial communities in broader taxonomic levels (phyla and order) revealing a large overall similarity, but no correlation with the phylogeny of the sponge.

However, the bacterial species in different sponges are more closely related among themselves than bacteria from sea water where they are. The geographic variation observed between the microbial communities of the sponges of the same species is due probably to the fact that sponges are filterers. Thus, the microbiota present in the local water will have a contribution in the microbial community present in the sponges.

\section{ENZYMATIC TESTS}

A total of 38 strains were isolated from sponges; 14 from $A$. fulva, 8 from $A$. viridis and 16 from $H$. heliophila. From these total, 19 showed enzymatic activity for at least one of the three tested substrates: starch, cellulose and casein. Lealem and Gashe (1994) suggest a value of $E I \geq 2$ as high potential degradation. Thus, among the 38 strains isolated, only $11(28.9 \%)$ show this potential; $1(2.7 \%)$ for starch, $1(2.7 \%)$ for cellulose and 9 (23.5\%) for casein. Only one strain isolated from $H$. heliophila (Hh9) was able to degrade the three substrates (Table I).

Baker (1998) says that bacteria is not only important in the nutritional process of sponges, but also in the degradation and transformation of marine plant biomass. Part of these bacterial isolates appear to take part in such ecological functions.

Nunes et al. (2011) demonstrated high potential degradation of macrophytes by bacterial cellulases, where cellulolytic activities presented the highest degradation halos as compared to the other substrates tested, indicating that the need to
TABLE I

Values of Enzymatic Index (EI) for strains isolated from sponges for the different substrates tested.

\begin{tabular}{|c|c|c|c|}
\hline Strains & Amylase & Cellulase & Caseinase \\
\hline Af. 2 & - & - & $4.0^{*}$ \\
\hline Af. 3 & - & - & 1.4 \\
\hline Af. 4 & 1.4 & - & - \\
\hline Af .5 & - & - & $3.3^{*}$ \\
\hline Af. 6 & - & - & $2.4^{*}$ \\
\hline Av. 2 & - & - & 1.3 \\
\hline Av. 3 & - & $3.0^{*}$ & 1.7 \\
\hline Av. 4 & - & - & 1.8 \\
\hline Av. 5 & - & - & $2.0^{*}$ \\
\hline Av. 6 & - & - & $2.4^{*}$ \\
\hline Av. 7 & - & - & $2.9^{*}$ \\
\hline Hh. 1 & 1.1 & - & 1.4 \\
\hline Hh. 3 & 1.2 & - & - \\
\hline Hh. 6 & 1.3 & - & $2.7^{*}$ \\
\hline Hh. 7 & - & 1.4 & 1.4 \\
\hline Hh. 9 & $2.3^{*}$ & 1.4 & 1.5 \\
\hline Hh. 10 & - & - & $4.6^{*}$ \\
\hline Hh. 12 & - & 1.2 & - \\
\hline Hh. 13 & - & - & $2.1^{*}$ \\
\hline
\end{tabular}

Af. = Aplysina fulva, Av. = Amphimedon viridis, $\mathrm{Hh} .=$ Hymeniacidon heliophila. $*=$ Values of EI $\geq 2.0$; Values of EI $<2$; (-) negative result, absence of halo.

decompose plants and seaweeds as a carbon source for metabolism influenced the high productivity of cellulase. In our work cellulolytic activity was found only in 4 (21\%) strains.

Mohapatra et al. (2003) and Feby and Nair (2010) found amylase as one of the most predominant enzyme produced by bacteria associated to sponges. Our results do not corroborate these data. Caseinase, a protease, was the most predominant enzyme detected in our study, present in $84.2 \%$ (16 strain) of the 19 that showed some enzymatic activity. The higher values of EI was found to caseinase too. Proteases occupy a central position with respect to their commercial applications. They are the most important hydrolytic enzymes and have been extensively studied since the advent of enzymology. 
Between the three sponges species presently studied, differences were observed in the number of isolates and their enzyme activity. This could be due to the differences in their physiological requirement and the ambient variation in the quality and quantity of the organic matter.

\section{BIOSURFACTANT PRODUCTION}

According Dhasayan et al. (2015), the spongeassociated bacteria for the biosurfactant production are scarcely reported; thus, the present study is contributing to increase this knowledge.

Of the 38 isolates obtained, 17 showed some emulsifying activity, a peculiar feature of the biosurfactants in general (Table II).

The presence of bacteria producing enzymes in sponges was reported early by some authors (Mohapatra et al. 2003, Feby and Nair 2010). These enzymes have an important role in helping sponges nutrition hydrolyzing complex molecules present in marine environment that sponges cannot directly absorb (Marx et al. 2007).

Six strains (35.29\%) were able to emulsify 80 to $100 \%$ of the substrate used for testing (diesel oil), in 24 hours of growth. Some colonies maintained their emulsion index or increased up to $100 \%$ in $48 \mathrm{~h}$ of growth.

Our results are quite satisfactory once Dhasayan et al. (2015) obtained of a total of 101 sponge-associated bacteria isolated, only 29 with positive result for biosurfactant production; and among these 29 positive isolates, just four presented high emusification activity. Moreover, corroborate Jennings and Tanner (2000) results that compared the amount of microorganisms producers of biosurfactants isolated from environments contaminated and not contaminated with hydrocarbons and observed a higher percentage of biosurfactants producers in uncontaminated environments. The authors concluded that environments never exposed to contamination also
TABLE II

Values of Emulsification index for the bacterial isolates from the sponges studied.

\begin{tabular}{|c|c|c|c|c|c|}
\hline Strain & $24 \mathrm{~h}$ & $48 \mathrm{~h}$ & Strain & $24 \mathrm{~h}$ & $48 \mathrm{~h}$ \\
\hline Af. 1 & $0 \%$ & $0 \%$ & Av. 6 & $60 \%$ & $100 \%$ \\
\hline Af. 2 & $0 \%$ & $0 \%$ & Av. 7 & $60 \%$ & $60 \%$ \\
\hline Af. 3 & $20 \%$ & $20 \%$ & Av. 8 & $0 \%$ & $0 \%$ \\
\hline Af. 4 & $0 \%$ & $0 \%$ & Hh. 1 & $80 \%$ & $80 \%$ \\
\hline Af. 5 & $0 \%$ & $0 \%$ & Hh. 2 & $40 \%$ & $40 \%$ \\
\hline Af. 6 & $0 \%$ & $0 \%$ & Hh. 3 & $0 \%$ & $0 \%$ \\
\hline Af. 7 & $20 \%$ & $60 \%$ & Hh. 4 & $80 \%$ & $80 \%$ \\
\hline Af. 8 & $80 \%$ & $80 \%$ & Hh. 5 & $0 \%$ & $0 \%$ \\
\hline Af. 9 & $40 \%$ & $40 \%$ & Hh. 6 & $0 \%$ & $20 \%$ \\
\hline Af. 10 & $0 \%$ & $0 \%$ & Hh. 7 & $100 \%$ & $100 \%$ \\
\hline Af. 11 & $0 \%$ & $20 \%$ & Hh. 8 & $80 \%$ & $80 \%$ \\
\hline Af. 12 & $0 \%$ & $40 \%$ & Hh. 9 & $0 \%$ & $0 \%$ \\
\hline Af. 13 & $0 \%$ & $0 \%$ & Hh. 10 & $0 \%$ & $0 \%$ \\
\hline Af. 14 & $80 \%$ & $100 \%$ & Hh. 11 & $0 \%$ & $0 \%$ \\
\hline Av. 1 & $40 \%$ & $80 \%$ & Hh. 12 & $0 \%$ & $0 \%$ \\
\hline Av. 2 & $0 \%$ & $0 \%$ & Hh. 13 & $0 \%$ & $0 \%$ \\
\hline Av. 3 & $20 \%$ & $20 \%$ & Hh. 14 & $0 \%$ & $0 \%$ \\
\hline Av. 4 & $0 \%$ & $0 \%$ & Hh. 15 & $0 \%$ & $0 \%$ \\
\hline Av. 5 & $60 \%$ & $100 \%$ & Hh. 16 & $0 \%$ & $0 \%$ \\
\hline
\end{tabular}

Af. $=$ Aplysina fulva, Av. = Amphimedon viridis and Hh. $=$ Hymeniacidon heliophila.

have microorganisms producing biosurfactants as the case of the environments studied in the present work.

An emphasis should be given to the study of these molecules, as they become increasingly promising as their use to replace highly aggressive chemicals to the environment, both in industry and in wastewater treatment, or remediation of contaminated sites (Carmo et al. 2014).

Four strains (Av.3, Av.5, Av.6 and Av.7) stood out among all isolates, because presented $\mathrm{EI} \geq 2$ for some of the substrates tested and also for having emulsification capacity between $20-100 \%$. Despite the production of enzymes has been reported for microorganisms isolated from the three sponges specie studied, our best results were found in bacteria isolated from $A$. viridis. Bonugli-Santos 
et al. (2010) describes marine fungi isolated from this species as producing laccase but we could not find in the literature reports of bacteria producing enzymes associated with this specie of sponge.

Strain Av.3 was identified by sequencing as Bacillus pumilus. According Jong et al. (2015), B. pumilus is a Gram-positive rod-shaped sporeforming soil bacterium but already isolated from marine environments. It is also used beneficially in the production of industrially relevant compounds, such as xylanases, lipases, and proteases.

Despite the geographic variation observed in their microbial community composition, $H$. heliophila occurring in two sites of the coast of Rio de Janeiro, Brazil, showed specific bacterial populations with some of them presenting potential for prospecting substances of biotechnological applications. The presence of bacteria with potential biotechnological application in the other species of sponges studied suggests that these organisms are a great source for the research of bioactive compounds.

\section{ACKNOWLEDGMENTS}

We are thanks to Fundação Carlos Chagas Filho de Amparo à Pesquisa do Estado do Rio de Janeiro (FAPERJ) and Conselho Nacional de Desenvolvimento Científico e Tecnológico (CNPq) for finnancial support.

\section{REFERENCES}

APHA - AMERICAN PUBLIC HEALTH ASSOCIATION. 2000. Standard Methods for the Examination of Water and Wastewater. $16^{\text {th }}$ ed., Washington, D.C., 1268 p.

BAIRAGI A, GHOSH KS, SEM SK AND RAY AK. 2002. Enzyme Producing Bacterial Flora Isolated from Fish Digestive Tracts. Aquac Int 10: 109-121.

BAKER JH. 1988. Epiphytic bacteria. In: Austin B (Ed), Methods in Aquatic Bacteriology. J Wiley \& Sons, Chichester, 425 p.

BANAT IM, FRANZETTI A, GANDOLFI I, BESTETTI G, MARTINOTTI MG AND FRACCHIA L. 2010. Microbial biosurfactants production, applications and potential. Appl Microbiol Biotechnol 87: 427-444.
BELOQUIA, DE MARÍAPD, GOLYSHIN PNAND FERRER M. 2008. Recent trends in industrial microbiology. Curr Opin Microbiol 11: 240-248.

BONUGLI-SANTOS RC, DURRANT LR AND SETTE LD. 2010. Laccase activity and putative laccase genes in marine-derived basidiomycetes. Fungal Biol 114: 863-872.

CARMO FL, SANTOS HF, PEIXOTO RS, ROSADO AS AND ARAUJO FV. 2014. Tank bromeliad water: Similar or distinct environments for research of bacterial bioactives? Braz J Microbiol 45: 185-192.

DHASAYAN A, SELVIN J AND KIRAN S. 2015. Biosurfactant production from marine bacteria associated with sponge Callyspongia difusa. Biotech 5: 443-454.

EGAN S, THOMAS T AND KJELLEBERG S. 2008. Unlocking the diversity and biotechnological potential of marine surface associated microbial communities. Curr Opin Microbiol 11: 219-225.

ESTEVES AIS, HARDOIM CCP, XAVIER JR, GONÇALVES JMS AND COSTA R. 2013. Molecular richness and biotechnological potential of bacteria cultured from Irciniidae sponges in the north-east Atlantic. FEMS Microbiol Ecol 85: 519-536.

FEBY A AND NAIR S. 2010. Sponge-associated bacteria of Lakshadweep coral reefs, India: resource for extracellular hydrolytic enzymes. Adv Biosci Biotechnol 1: 330-337.

JENNINGS EM AND TANNER RS. 2000. Biosurfactant - producing bacteria found in contaminated and uncontaminated soils. Proceedings of the 2000 Conference on Hazardous Waste Research, p. 299-306.

JONG A, VAN HEEL AJ, MONTALBAN-LOPEZ M, KRAWCZYK AO, BERENDSEN EM AND BENNIK MW. 2015. Draft Genome Sequences of Five SporeForming Food Isolates of Bacillus pumilus. Genome Announc 3: e01539-14.

KAMKE J, TAYLOR MW AND SCHMITT S. 2010. Activity profiles for marine sponge-associated bacteria obtained by $16 \mathrm{~S}$ rRNA vs $16 \mathrm{~S}$ rRNA gene comparisons. The ISME Journal 4: 498-508.

KIRAN GS, ASHA D, LIPTON AN, SELVIN J, ARASU MV AND AL-DHABI NA. 2014. Melanin-templated rapid synthesis of silver nanostructures. J Nanobiotechnol 12: $1-13$.

LEALEM F AND GASHE BA. 1994. Amylase Production by a Gram-Positive Bacterium Isolated from Fermenting Tef (Eraglostis tef). J Appl Bacteriol 77: 348-352.

MARX JC, COLLINS T, D'AMICO S, FELLER G AND GERDAY C. 2007. Cold-adapted enzymes from marine antarcticmicroorganisms. Mar Biotechnol 9: 293-304.

MOHAPATRA BR, BAPUJI M AND SREE A. 2003. Production of industrial enzymes (amylase, carboxymethylcellulase and protease) by bacteria isolated from marine sedentary organisms. Acta Biotechnol 23: 75-84. 
MUYZER G, WAAL EC AND UITTERLINDEN AG. 1993. Profiling of complex microbial populations by denaturing gradient gel electrophoresis analysis of polymerase chain reaction - amplified genes coding for 16S rRNA. Appl Environ Microbiol 59: 695-700.

NÜBEL U, GARCÍA-PINCHEL F AND MUYZER G. 1997. PCR primers to amplify $16 \mathrm{~S}$ rRNA genes from Cyanobacteria. Appl Environ Microbiol 63: 3327-3332.

NUNES MF, DA CUNHA-SANTINO MB AND BIANCHINI IJR. 2011. Xylanase and cellulase activities during anaerobic decomposition of three aquatic macrophytes. Braz J Microbiol 42: 75-83.

ORTEGA-MORALES BO, CHAN-BACAB MJ, MIRANDATELLO E, FARDEAU ML, CARRERO JC AND STEIN T. 2008. Antifouling activity of sessile bacilli derived from marine surfaces. J Ind Microbiol Biotechnol 35: 9-15.

RAMOS SV, RUIZ MCP, CASARRUBIAS MLB, MUÑOS JVT, CHAVIRA BER AND MOORÍLLON GVN. 2010. Selection of Biosurfactan / Bioemulsifier-Producing Bacteria from Hydrocarbon Contaminated Soil, Braz J Microbiol 41: 668-675.
SACHDEV DP AND CAMEOTRA SS. 2013. Biosurfactants in agriculture. Appl Microbiol Biotechnol 97: 1005-1016.

SCHMITT S, TSAI P, BELL J, FROMONT J, ILAN M AND LINDQUIST N. 2012. Assessing the complex sponge microbiota: core, variable and species-specific bacterial communities in marine sponges. The ISME Journal 6: 564576.

SKARIYACHAN S, RAO GA, PATIL MR, SAIKIA B, BHARADWAJ KV AND RAO GJ. 2014. Antimicrobial potential of metabolites extracted from bacterial symbionts associated with marine sponges in coastal area of Gulf of Mannar Biosphere. India Lett Appl Microbiol 58: 231-241.

WEBSTER NS AND TAYLOR MW. 2012. Marine sponges and their microbial symbionts: love and other relationships. Environ Microbiol 14: 335-346.

WILLIAMS ST, GOODFELLOW M, ALDERSON G, WELLINGTON EMH, SNEATH PHA AND SCKIN MJ. 1983. Numerical Classification of Streptomyces and Related Genera. J Gen Microbiol 129: 1743-1813. 